\title{
Implementation of The Teachers and Lecturers Law
}

\author{
Sulistyani Eka Lestari \\ Universitas Sunan Bonang Tuban \\ sulis usb@yahoo.com
}

\section{Article History $\quad$ Received : January $11^{\text {th }} 2021$}

Revision : Marchy $17^{\text {th }} 2021$

Publication : June $30^{\text {th }} 2021$

\begin{abstract}
Law of Teachers and Lecturers (UUGD) as a form of recognition and appreciation to teachers and lecturers' profession. In the implementation of UUGD, teacher governance is often very complex and faced with various problems. The question in this study is why teacher governance has not been good. This study uses the qualitative approach chosen because of its open and flexible nature. Through open interviews (individuals and groups) as well as several focus group discussions (FGD) FGD found that teacher governance problems in the implementation of UUGD are related to many issues, for example: the lack of clear definitions of teachers and their implications on additional tasks (structural) and functional supervisors, curriculum changes, quantity-distribution-mutation of teachers, qualityspecialization-workshops of civil servants and non-civil servants teachers, teacher protection, teacher awards, and teacher professional organizations.
\end{abstract}

Keyword : education, teachers, legislation, governance,

\section{INTRODUCTION}

The Law's birth evidence recognition of the profession of teachers and lecturers who were previously underappreciated on Teachers and Lecturers (UUGD)(Darmawan, 2020). Teachers and lecturers are the vanguards in implementing education in filling the national development in education. Education is held to prepare human resources with character, competence, and ability to fill the future of nation and state(Dewi et al., 2018; Hasan, 2015).

UUGD was passed in 2005 to improve national education, both in quality and quantity, so that Indonesian human resources can be more faithful, creative, innovative, productive, and knowledgeable about improving the entire nation's welfare(Andina, 2018). According to the mandate of Article 31 paragraph (3) of the 1945 Constitution, the Government strives and organizes a national education system that increases faith and piety and noble morals to educate the nation's life. Improvement of the quality of national education referred to in the UUGD include, the national education system, qualifications and competencies of teachers and lecturers, curriculum standards used, and other matters. UUGD is expected to be a breakthrough to create qualified educators(UU No 14 Tahun 2005). Still, it turns out 
that some things are not separated from the shortcomings and may need to be improved immediately (both in terms of concept and implementation).

In fact, out of about 3.9 million teachers under the Ministry of Education and Ministry of Education management, there are still as many as one million teachers who have not met the minimum qualification requirements of S-1/D-4 academic qualifications. Of these teachers, only about 1.9 million teachers have been certified(Suyanta et al., 2020). To comply with the UUGD, the Government is committed to completing the certification process for teachers gradually, making improvements in the management and improvement of teacher professionalism, assigning educational institutions (LPTK) to implement the Teacher Professional Education program (PPG) to produce qualified teachers, requiring the appointment of new teachers only for PPG graduates, strengthening the policy of recruitment and distribution of qualified teachers, sending graduates of LPTK to educate in the outer, disadvantaged, and leading areas (3T) throughout Indonesia(Quddus, 2020). In the implementation of UUGD, teacher governance often faces a variety of complex obstacles. Especially for teachers, the problem is still lame the availability of teachers between educational institutions and interregional; teacher certification programs that are still eligible with problems (program implementation, financing); the insignificant impact of various teacher qualification and competency improvement programs on improving the quality of learning and student learning outcomes; inadequate capacity of LPTK, especially private LPTK in creating qualified teachers; development and career path of teachers that are still unclear; efforts to protect teachers are still low; lack of attention to improving teacher welfare; discrimination against private teachers with state teachers, honored teachers and civil servant teachers, as well as UUGD that is no longer relevant to the national dynamics(Salam, 2020). Realizing the complexity of teacher governance issues, the formulation of the question raised in this study is why teacher governance has not been good? This research aims to find out and give a complete picture of why teacher governance has not been good. This study's results are expected to obtain a new substance and paradigm on teacher governance to contribute the results of thought to the Government, especially in efforts to improve teacher governance in Indonesia.

\section{METHOD}

This study uses a qualitative approach. This approach was chosen because of the open and flexible nature of qualitative approaches. This approach is expected to be obtained as much input from the speakers and informants, so that a complete picture of the problem can be obtained. Primary data collection techniques are conducted by interview. This technique has a variety of forms and uses, but in this study will be used the most common type, namely: face-to-face interviews, both with individuals and with groups (focus group interview)(Boateng, 2012). Interviews 
are conducted with unstructured interviews that provide more space for informants and the questions asked are open-ended, thus enriching data acquisition. To obtain primary data, interviews were conducted on various informants, namely resource persons who work as teachers and academics, related to professional governance issues, ministry officials related to the management of the teaching profession, and representatives of teacher organizations and lecturers. Interviews are recorded and equipped with field notes by researchers.

\section{RESULTS AND DISCUSSION}

The key to the success of education policy is the efficiency of the service process, quality, and policy implementation certainty. To face these challenges, one of the prerequisites that need to be developed is a high commitment to apply the noble values and principles of good governance in realizing the state's ideals and objectives, which was mandated in the Opening of the 1945 Constitution. United Nations Development Program (UNDP) in its policy document entitled "Governance for Sustainable Human Development" (1997), defines governance as the implementation of authority / power in the field of economics, politics, and administration to manage various state affairs at every level and is an instrument of state policy to encourage the creation of welfare conditions and social cohesion in society(UNDP, 2017). The word governance is taken from the Latin word, governance which means directing and controlling(Bekker, 2015). Meanwhile, governance is the process of managing various areas of life (social, economic, political, and so on) in a country as well as the use of resources (natural, financial, human) in a way that is following the principles of justice, efficiency, transparency, and accountability(Pemsel et al., 2014). Government or Government in English is defined as the authoritative direction and administration of the affairs of men/women in a nation, state, city, etc. In terms of semantics, governance means governance and good governance means good governance. Good governance is defined as the performance of an institution, such as the performance of a government, company or community organization(Addink, 2018).

If the term is referred to in the original English word "governing," then the meaning is directing or controlling(Keegan, 2020). Therefore good governance can be interpreted as an action to direct, control, or influence public problems. From the various understandings above, it can be concluded that good governance is both in the process and the result. All government elements can move synergistically, do not clash with each other, gain support from the people, and be free from anarchist movements that can hinder the process and pace of development. The government can also be said to be good if productive and show results with indicators of people's economic ability to increase, both in terms of productivity and in purchasing power; his spiritual well-being is enhanced by indicators of a sense of security, happiness, and a high sense of nationality. Education in Achieving National Development 
Developed countries, where there is a "labour surplus economy", development capital can not be suspended only on the availability or possible availability of investment funds. Such development in addition to being too expensive will also experience obstacles if at any time the source of investment becomes limited, both from the Government and the community (Ranis, 2004).

Meanwhile, a large population as human resources should be used as an advantage, not the other way around. In GBHN Year 1988 stated: "a very large population, if it can be built and deployed as an effective workforce will be a large development capital that is very profitable for development efforts in all fields." This problem is not only due to limited investment funds, but also as a strong foundation for community participation in development to ensure the continuity and success of national development. Indonesia's good geographical and political condition, as well as geostrategic position become a major capital in national development efforts. Such large capital can be used effectively and efficiently, especially if managed wisely and supported by the high capabilities of the managers and their people. This fact shows that the quality of human resources plays an important role in a nation's welfare. Improving the quality of human resources to become a prosperous country can start from building human resources through education or holding the principle of education first, prosperity follows. Community participation as a subject in development is essential. The development will not achieve optimal results and the success achieved cannot be enjoyed by all walks of life evenly without their active participation. However, certain boundaries involve the active participation of every layer and members of the community sometimes encounter various obstacles and problems, among which are constraints on ability and competence.

The challenge faced is how continuously efforts are made so that the constraints of the capabilities possessed by all levels and members of the community can be resolved to actively participate in national development and enjoy the results of development achieved. The most effective effort to overcome these obstacles is through education. The Role and Function of Teachers in National Education means a person whose job (livelihood, profession) teaches(Pusat Bahasa Departemen Pendidikan Nasional, 2018). This understanding gives the impression that a teacher is a person who does activities in the field of teaching. The term teacher is synonymous with the word teacher and is often distinguished by the term educator. Presents terms related to the naming of educational and teaching activities. He then concluded that the entire terms were collected in the word educator. This is because the whole term refers to someone who provides knowledge, skills or experience to others(Maya, 2017).

Furthermore, teachers are adults who are responsible for guiding learners in terms of physical and spiritual development to achieve maturity, fulfill their duties as God's beings, independent individual beings, and social beings(Nazirwan, 2019). Al-Gazali does not distinguish the words teaching and education, so teachers and 
educators are also indistinguishable (Rusn, 2009: 63). In UUGD itself, teachers are a term for positions, positions, and professions for someone who devotes himself to education through educational interactions in a patterned, formal, and systematic way. Teachers are professional educators with the primary task of educating, teaching, guiding, directing, training, assessing, and evaluating learners in early childhood education pathways of formal education, primary education, and secondary education.

Professional teachers will be reflected in the implementation of devotion tasks characterized by expertise, both in materials and methods. In addition to his expertise, a professional teacher's figure is shown through his responsibility in carrying out all his devotion. Professional teachers should assume and carry out their responsibilities as teachers to their students, parents, society, nation, country, and religion. As a teacher or educator, teachers are one of the determining factors in every educational effort's success. That is why every educational innovation, especially in the curriculum and the improvement of human resources resulting from educational efforts, always boils down to the teacher factor(Tarigan, 2013). This shows how existent the role of teachers in the world of education. Teachers become a factor that determines the quality of education because teachers come face-to-face with the students in the classroom's learning process. In the hands of teachers, the quality and personality of learners are formed. Therefore, it is necessary to be a competent, responsible, skilled, and highly dedicated teacher. Teachers are curriculum running curriculum and education system that exist without supported by teachers' ability, everything will be in vain.

Teachers are competent and responsible, especially in controlling the development of learners to the maximum point. The ultimate goal of the entire teacher mentoring process is the growth of a complete adult person. Along with the rapid advancement of information technology, teachers no longer act as information presenters. Teachers should also act as facilitators, motivators, and mentors that provide more opportunities for students to find and process their information (. Thus, the teacher must also continuously improve his skills and always follow the development of science and technology to face various challenges. The rapid development of education in line with technological advances and globalization needs to be balanced by the main actors of education's ability, in this case, teachers. For some teachers, facing rapid changes in education can have the impact of anxiety and fear. Changes and updates in general bring a lot of anxiety and discomfort. The implications of change in education are not easy, as they have technical and praxis consequences and psychological consequences for teachers. For example, curriculum changes or changes in education policy. The change is not just a change in the structure and content of the curriculum or just a change in the content of learning, but a change that demands a change in the teachers' attitudes and behaviors-for example, changes in character, mentality, methods, and strategies in 
learning. Teachers in carrying out their professional duties have duties and responsibilities that are not light. Therefore, the teacher must have and master his competence and at the same time know his rights and obligations so that he becomes a truly professional teacher figure. Teacher as Professional Occupation Professionalism comes from the word profession which means a work field that a person wants or will pursue.

The profession is a position or job that demands expertise from its members. This means that careless people cannot be done who are not trained or specially prepared to do the work(Dwi Kesuma Putri \& Imaniyati, 2017). Also said that professions are also defined as certain positions or occupations that require special knowledge gained from intensive academic education. While the professional shows on the appearance of someone who suits the demands that it should be. Professional is a job or activity performed by a person. It becomes a source of income for life that requires skills, skills, or skills that meet certain quality standards or norms and require professional education(Arifa \& Prayitno, 2019). Teacher professionalism is the condition, direction, value, purpose and quality of skill and authority in education and teaching related to the work of a person who becomes a livelihood. Professional teachers are teachers who have the required competencies to perform educational and teaching tasks. Competencies include professional knowledge, attitudes, and skills, both personal, social, and academic. When analyzed again, the teacher in the professional context of the above professional understanding and characteristics can be interpreted as the teacher's profession in carrying out his work not only teaching and providing information in the form of lesson materials only, but has a purpose. In carrying out their duties and responsibilities, special abilities are required based on specific knowledge concepts. Based on UUGD, Article 10 paragraph (1) states that teacher competencies include pedagogic competencies (ability to manage student learning), personality competencies (steady personality skills, noble character.

UUGD mandates that teachers must have academic qualifications, competencies, educator certificates, physical and spiritual health, and realize national educational goals. This research is no longer new research in its field, if it is seen as a teacher as a profession. Various studies on teacher professionalism are found in LPTK and universities, especially since UUGD was passed more than ten years ago. In particular, international institutions such as the World Bank even have their own task force related to teachers, through the Teacher Performance and Accountability (KIAT Guru World Bank) project. The research conducted by the Social Welfare Team will focus more on the implementation of UUGD which should be the standard for the development of the teacher's profession. From direct studies in two provinces that are expected to represent real conditions in the field, it is expected that clarity can be found, whether this UUGD has been ideal in answering 
the teacher profession's demands or rather too boxed in the very noble profession of an educator.

The study results in the field will be seen the need for the UUGD to be revised or completely overhauled to answer the demands of future development. According to the National Staffing Agency data, teacher governance in the Implementation of UUGD at the Regional Level According to the National Staffing Agency data, from all existing civil servants (4,538,154), approximately 1,712,848 (37.74 percent) civil servants have available positions of educators / teachers.3 Data with the difference of 500 thousand $(1,205,227$ CIVIL SERVANTS GTK) delivered by the Ministry of Education who also said there are about 962,169 non-civil servants GTK throughout Indonesia. 4 The quantity of human resources is so large that must be managed well to benefit all Indonesians.

According to data from the Ministry of Education and Culture (Kemendikbud), the rapid growth in teachers' number makes the number of teachers in Indonesia excessive. That is, there is indeed an excess of teachers in quantity. But the teacher organization reveals different things in the field, in fact (for the intermediate level) there is a shortage of subject teachers. For example, there is an over-teacher for citizenship and economics lessons, while for religious lessons, there is a shortage of teachers. Finally came the case of the teacher who only taught 4 hours of lessons, and the rest was spent on pickets Monday s.d. Friday.

Nationally, the Government should not distinguish teachers' status (private / honorer / state) because teachers are the spearhead of coaching the next generation, so the main goal is the achievement of qualified teachers. But it's good that the Government, through existing laws, regulates the number of private teachers so that the quality doesn't go down. Arrangements can start from formation, appointment, and certification so that the rapid growth of teachers due to the extraordinary animo of the general public can be managed properly. Also, it is necessary to be reminded not to let teachers be paid cheaply or want to be paid cheaply. For example, for teachers who teach at SLB, the majority teach sincerely without pay, especially considering the foundation that houses the nonprofit. The teachers' hope, especially non-civil servant teachers are that if there is an appointment of civil servants, it is better to take precedence over honorer teachers who have long taught in schools, both public and private. The distribution and appointment of honorary teachers are already in our education system. Disdik can initiate the establishment of local regulations on the distribution of teachers with legal consequences that bind the local Government and the teachers themselves. Furthermore, related to teachers' procurement for the teacher procurement program, it has been handed over to the LPTK to implement. Based on one of the LPTK in DIY Province, the budget is provided by the Government and then allocated to each LPTK. 
There are specific guidelines in the form of books in practice, such as the Teacher Certification Program Manual and the Determination of SM-3T PPG Participants. LPTK needs to keep teachers' quality low because currently many education of prospective teachers held in universities are not clear results. The quality of teachers produced by the LPTK is not by the needs in the community. It should also be considered that the graduates of some teacher schools are lower in quality when compared to graduates of public universities because the learning methods are not suitable. Therefore, higher education printer teachers should be reminded to print qualified teachers. Also, the issue of teacher quantity concerns the functional position of teachers. The mechanism of moving positions from functional teachers to structural positions has not been regulated. But if a teacher wants to move to a structural position, then the functional position must be removed. Also, the qualification requirements for new positions must be met, especially the need to pass education and training as a determinant of qualifications or not as stated in PP No. 13Year 2002. Teachers who move tasks between provinces, the district /city education office through the Agency for Staffing, Education, and Training (BKPP) submits a mutation application to the destination area. After receiving the answer to the application with a statement will be received by the destination region or province, the mutation process will continue.

The same applies to mutations between districts or between cities. Suppose the transfer of tasks requested is still in the district / city concerned. In that case, the district/city concerned education office / city concerned will see the projection / planning needs first by considering the equalization of the quality of education in schools. Furthermore, the issue of teacher workload. Teacher workload is compiled in PP No. 74 Year 2008 on Teachers who are derivatives of UUGD. Teacher assignments can be said to be very difficult, ranging from preparing, carrying out, evaluating, guiding students, and carrying out other additional tasks. As a profession, the obligation from planning to evaluation will look simple. But in practice, there are various demands, so that if described there will be dozens of tasks that must be carried out by teachers, in addition to the demands of teaching a minimum of 24 hours of lessons and administrative procedures that must also be reported. The Ministry of Education has initiated an alternative that teachers' working hours can amount to 16 hours only. A 24-hour fixed setting of 17 to 24 is calculated based on conversion, for example when a teacher is picketing or teaching extracurriculars at his own school. The principal is also not charged with having to teach from the current need to teach 6 hours. The principal performs managerial functions with an emphasis on controlling. Teachers are expected to be part of an education governance system that requires teachers to master organizing education including budgeting. Teachers as a core part of the education process whose core business is learning are often involved in the implementation of education that requires them to deal with a letter of accountability (SPJ) using complex funds. 
Teachers ultimately have to deal with administrative issues that have nothing to do with the main task. They should be able to administratively report budgets for learning activities that they cannot understand its components. Teachers are also faced with the challenges of technological development. The Government continues to conduct teacher quality improvement programs by utilizing technology (remotely) and through books/ modules. Mastery of technology is important for teachers considering that today, amid global developments and technological advances, civilization's progress is no longer measured materially, such as natural resources, industrial advances, factories, weaponry, and other infrastructure, but measured on the quality of human resources. For the quality of human resources, two main things are essential to be captured and mastered: information and knowledge. The challenge is not all teachers are technologically literate, but there is still hope of improving this condition in the future.

Protection of teachers in the implementation of duties is found in Permendikbud No. 10 of 2017 which expressly mentions anyone who is obliged to provide legal protection to teachers if there are legal problems in the implementation of their duties, in Article 3 Permendikbud No. 10 of 2017, such protection is the obligation of the Government; Local Government in accordance with its authority; Education Unit; Professional Organizations; and/or Society. The Ministry of Education has signed an MoU with the High Prosecutor's Office, kpk, and also with the police related to the title of internal cases between the parties who file so that it does not immediately come out the notification that the results of the investigation are complete (P21) in the Prosecutor's Office. There are already guidelines based on Permendikbud No. 10 of 2017 on Protection for Educators and Educational Personnel, which initiated the establishment of a team to prevent violence in schools and the preparation of SOPs in case of violence in schools. Based on the findings in the field through discussions with teachers, teacher organizations, and local governments in the field of teachers in the provinces of DIY and South Sulawesi, to this day, various events have damaged the dignity and appreciation of the community towards teachers. This is because there is no social construction in the form of regulation set by the center, then followed up at the regional level, to be realized at the education unit's level, especially through socialization to the parents of students. Protection of teachers is difficult for the central Government because handling teacher problems in the area are the duty of the local Government. Still, this arrangement does not lead to reduced complaints of troubled teachers to the central Government. The Ministry of Education does not stop reminding teachers of the existence of Law No. 23 of 2002 on Child Protection so that child disciplinary efforts are not carried out harshly.

Especially since information is quickly spreading everywhere. The hope of the teachers is the strengthening of protection because the main purpose of the teacher if doing the actual punishment is to improve the student itself. Overall 
ranging from the Law to PP and Candy has actually explained about the importance of teacher protection, or teachers must be protected legally. However, technical or more specific explanations regarding legal protection do not exist. This encourages the strengthening described in the local form, such as through perda or Pergub / Perbup / Perwali. Protection of security is also very determining the professionalism of teachers. If we look at some of the cases that have happened to teachers lately, especially with the ease of community groups on behalf of nongovernmental organizations and even the mass media that participated, in general we feel worried and conclude that there is a tendency of ideal conditions have not fully materialized. There have been several cases of professional mistreatment of teachers such as professional harassment, physical beating of teachers. Treatment from the community or parents who sometimes do not support the teacher's sense of security in carrying out duties, for example there are complaints or protests against punitive actions by teachers in which parents react violently to acting outside the limits without going through legal procedures. As a result, teachers become reluctant to take action and justification occurs. It is recognized that the teacher as an ordinary human being certainly experienced certain mistakes, but, certainly, the teacher did not intend to hurt his students as an official committed abuse

\section{CONCLUSION}

The Law of Teachers and Lecturers' birth shows that there is an appreciation for the profession of teachers and lecturers in the national education scene. The birth of UUGD is expected to encourage education actors, especially in this case teachers as the vanguard of education implementation in order to carry out their profession in a more ideal and professional. Although it has been strengthened in the form of Law, but in the implementation of teacher governance has not been implemented properly. Some of the problems faced related to teacher management start from a very broad definition of teacher, arrangements that often change, and a unifying container that is not felt when needed. Not to mention the quantity problem that affects the quality of teachers. As a professional educators, teachers' main task is to educate, teach, guide, direct, train, assess, and evaluate learners' early childhood education pathways of formal education, primary education, and secondary education. As the vanguard and forefront of teaching, teachers hope to continue improving their quality to improve the quality of education with the Government's support. That is, not the infrastructure that takes precedence, but the quality of teachers (superstructure) as the main buffer of building the education system. Teachers' quality includes educational qualifications, rank, leadership, products (outputs) resulting from their work, and the main thing is competence or expertise. There is a desire from some teacher groups to provide support from advocacy organizations for teachers faced with legal problems. Experience also 
leads to the need for national regulation in the form of laws on teacher protection. The content of the arrangements regarding the protection of teachers can be adopted from various good practices of existing teacher organizations. Especially regarding the organization of the teaching profession, there needs to be one professional organization, because the Law mandates one professional organization. Still, it opens the opportunity for the establishment of various teacher organizations. The various teacher organizations that are formed need to equate the understanding of what form of professional organization of teachers is best for teachers. Whether it will merge with PGRI, or become a new organization with a form of membership or management that (for example) is confederate. This professional organization will also regulate the rights and authority of its members. Professional organizations can also regulate things other than UUGD mandated, such as opportunities for foreign teachers to teach in schools in Indonesia or organize schools that can cooperate with foreign institutions. With one clear professional organization, members strengthen their profession through organization.

\section{REFERENCES}

Addink, G. H. (2018). Good Governance: Importance in Practice, Theories and Definitions. Halu Oleo Law Review. https://doi.org/10.33561/holrev.v1i1.2347

Andina, E. (2018). Efektivitas Pengukuran Kompetensi Guru. Aspirasi: Jurnal Masalah-Masalah Sosial. https://doi.org/10.46807/aspirasi.v9i2.1103

Arifa, F. N., \& Prayitno, U. S. (2019). Peningkatan Kualitas Pendidikan: Program Pendidikan Profesi Guru Prajabatan dalam Pemenuhan Kebutuhan Guru Profesional di Indonesia. Aspirasi: Jurnal Masalah-Masalah Sosial. https://doi.org/10.46807/aspirasi.v10i1.1229

Bekker, M. C. (2015). Project Governance - The Definition and Leadership Dilemma. Procedia - Social and Behavioral Sciences. https://doi.org/10.1016/j.sbspro.2015.06.117

Boateng, W. (2012). Evaluating the Efficacy of Focus Group Discussion (FGD) in Qualitative Social Research. International Journal of Business and Social Science.

Darmawan, C. (2020). IMPLEMENTASI KEBIJAKAN PROFESI GURU MENURUT UNDANG-UNDANG REPUBLIK INDONESIA NOMOR 14 TAHUN 2005 TENTANG GURU DAN DOSEN DALAM PERSPEKTIF HUKUM PENDIDIKAN. Wacana Paramarta: Jurnal Ilmu Hukum. https://doi.org/10.32816/paramarta.v19i2.86

Dewi, M. P., Rahmatunnisa, M., Sumaryana, A., \& Kristiadi, J. B. (2018). Ensuring Service Quality in Education for Indonesia's Sustainable Education. Journal of Social Studies Education Research, 9(4), 65-81.

Dwi Kesuma Putri, A., \& Imaniyati, N. (2017). Pengembangan Profesi Guru Dalam Meningkatkan Kinerja Guru (Professional Development of Teachers in Improving the Performance of Teacher). Jurnal Pendidikan Manajemen Perkantoran.

Hasan, I. (2015). Pengembangan Kurikulum LPTK (Ibnu Hasan). Islamadina.

Keegan, M. G. (2020). Oxford university press. In ITNOW. 
https://doi.org/10.1093/ITNOW/BWAA110

Maya, R. (2017). Pengertian Guru. Edukasi Islami: Jurnal Pendidikan Islam.

Nazirwan, N. (2019). PERAN GURU MENURUT JOHANN HEINRICH PESTALOZZI DALAM MENGHADAPI DIGITAL NATIVES. Al-Ashlah: Journal of Islamic Studies.

Pemsel, S., Wiewiora, A., Müller, R., Aubry, M., \& Brown, K. (2014). A conceptualization of knowledge governance in project-based organizations. International Journal of Project Management. https://doi.org/10.1016/j.ijproman.2014.01.010

Pusat Bahasa Departemen Pendidikan Nasional. (2018). Kamus Besar Bahasa Indonesia versi online. Kemdikbud.

Quddus, A. (2020). Implementasi Technological Pedagogical Content Knowledge (TPACK) dalam Pendidikan Profesi Guru (PPG) PAI LPTK UIN Mataram. Jurnal Tatsqif. https://doi.org/10.20414/jtq.v17i2.1911

Ranis, G. (2004). Labor Surplus Economies. Yale University Economic Growth Center Discussion Paper. https://doi.org/10.22004/ag.econ.28480

Salam, E. M. (2020). Pelatihan PTK: Alternatif Solusi Dalam Meningkatkan Kemampuan Guru Menyusun Karya Tulis Ilmiah. Jurnal Karya Abdi.

Suyanta, S., Muharram, M., Mulbar, U., Rauf, B., Agung, M., Ganefri, G., Ponto, H., Sila, I. N., Wahid, A., Parenreng, J. M., Yasdin, Y., Astuti, S. R. D., Puspita Sari, A. R., \& Tyas, R. A. (2020). Educational LPTK, Non-educational LPTK, and Non-LPTK Students' Intention to Become Teacher. Universal Journal of Educational Research. https://doi.org/10.13189/ujer.2020.081232

Tarigan, P. B. (2013). pengertian kompetensi guru. Journal of Chemical Information and Modeling.

UNDP. (2017). UNDP Strategic Plan, 2018-2021. Executive Board of the United Nations Development Programme, the United Nations Population Fund and the United Nations Office for Project Services.

UU No 14 Tahun 2005, R. (2005). Undang-undang Guru dan Dosen. Produk Hukum. 